\title{
Building Failure and Collapse in Nigeria: the Influence of the Informal Sector
}

\author{
Fagbenle, Olabosipo I. \\ Department of Building Technology \\ Covenant University, Ota, Ogun State, Nigeria \\ E-mail: olafagbenle@yahoo.com
Oluwunmi, Adedamola O. (Corresponding author)
Department of Estate Management
Covenant University, Ota, Ogun State, Nigeria
E-mail: damilive@luxmail.com

\begin{abstract}
The occurrence of building failure and collapse has become a major issue of concern in the development of this nation as the magnitudes of this incident are becoming very alarming. This paper therefore examines the incidents of building failure/collapse in Nigeria. By focusing on six major states from each of the six geo-political regions of the country, the paper examined the contributory role of the informal sector to this decadence. The study indicated that the building failure and collapse stem principally from hasty construction, low quality workmanship, poor supervision, inexperience (use of incompetent hands), ignorance, evasion/ non-compliance with building regulations and non enforcement of building quality, standard and control on construction site/market. This study has revealed that more than $70 \%$ of the reported cases of building collapse in Nigeria stemmed from the informal sector. It further showed that $70-0 \%, 23-3 \%$ and $6.7 \%$ of the reported cases occurred in private, public and corporate organizations respectively. In this paper, it is concluded that it is important to educate or giver further advice to the government and the governmental agencies to be proactive to their duties in order to curb/reduce this negative image.
\end{abstract}

Keywords: Building Construction, Collapse, Failure, Influence, Informal-sector, Nigeria

\section{Introduction}

Building collapse, though a common phenomenon all over the world is more rampant and devastating in the developing countries. The incidence of building failures and collapses has become major issues of concern in the development of this nation as the frequencies of their occurrence and the magnitude of the losses in terms of lives and properties are now becoming very alarming. In fact, building collapse has now become a familiar occurrence, even to layman on the street in Nigeria.

Failure in building can be described as the inability of the building components not being adequate to perform what are normally expected or required of those components. On the other hand, when part or whole structure has failed and suddenly gave way in a way that as a result of this failure, the building could not meet the purpose for which it was intended, the building has collapsed. Failures in building can occur during different stages of construction process itself, as well as after. In Nigeria, the common causes of building collapse have been traced to bad design, faulty construction, use of low quality materials, hasty construction, foundation failure, lack of proper supervision, ineffective enforcement of building codes by the relevant Town Planning Authorities, lack of proper maintenance e.t.c. (Folagbade, 2001 and Badejo, 2009)

Cases of building collapse are not restricted by climatology or level of urbanization as they cut across cultural and ethnical barriers. Many cases of building collapse have been reported in Nigeria. For instance, Folagbade (2001) and Chinwokwo (2000) enumerated forty-two (42) cases of building collapse as occurring between 1980 and 1999 in Nigeria while Makinde ( 2007) listed fifty-four (54) cases occurring between January 2000 and June 2007 alone. Building collapse has also been observed to cut across the different categories of building - private, corporate or public. Folagbade (2001) showed that of the twenty-five (25) reported cases of building collapse between 1980 and 1999 in Lagos State, private (76\%), corporate (12\%) and government or public buildings (12\%) accounted for these proportions. Also, building collapse is no respecter of size of the structure. Amusan (1991) reported that Barnawa flat disaster in 1977 was a three-storey building, a public building (Secondary School) which collapsed in March 1988 at Ibadan was two-storey building, the collapsed show-room for cars in Lagos in 1987 was just a storey building while that of the Primary School in IIoabuchi, River State in July 1991 was a bungalow building. Folagbade (2001) also reports that the Abuja building which collapsed in March, 1993 and the one at Ojuelegba in 1999 were both multi-storey buildings. The memory of the incidents of two separate building collapses that occurred at Ebute-Meta area of Lagos State and Kano State which killed several people in 2007 still lingers on. Also reported was the fence of a Nursery and Primary School that collapsed at Olomi area, Ibadan, in March, 2008, thereby killing thirteen (13) pupils of the School. The death of over 50 students of Saque Comprehensive College, Port Harcourt in1990 was as a result of the owner attempting to construct additional 
floors on structurally unsafe walling. Similar trends of conversion were observed in a collapsed Mosque building in Mushin area, Lagos in 2001 and multi-storey commercial/residential building in Ebute-Meta also in Lagos state in which several people were killed. Some of the cases of building collapse are also as a result of ignorance on the part of developers and unauthorized conversion of buildings. Amusan (1991) asserts that the 1988 building collapse at Mushin, Lagos occurred when an attempt was made to raise the existing building by another floor. Also, operational conversion caused the collapsed school building at PortHarcourt.

As posited by Adebayo (2000), the skill, experience and personal ability of the workmen involved in the building construction is of utmost importance in creating value. However, this assertion can only be relied upon in a situation where the developers/contractors are capable and willing to appreciate quality and be ready to pay a commensurable reward in this regard. Ward (1979) classifies the contracting firms into three categories namely large sized, medium sized and small sized firms. He opined further that while small sized firms deal mainly with minor works, repair and maintenance of buildings in a particular locality, the large sized firms on the other hand, deal with a wide range and size of activities on a national or even global basis. Ademoroti (1991) identifies three types of Acts in the country as: Public Health Act; The Town and Country Planning Acts; and the Building Regulation Act. According to the author, the public Health Act deals with all aspects of health sanitation and environment as relating to the inhabitants of buildings. The Town and Country Planning Act deals with the general location and planning in the town and country aspect such as spatial distribution of buildings, highways/roads, schools, hospitals, sewage and drainage systems as well as other physical infrastructures. The Building Regulation Act represents laws that relate specifically to the control of the construction of buildings. It was further stressed that an existing regulation is meaningless without carrying with it a mechanism to ensure compliance because the average citizen does not obey a law that is not enforced. To this end, five types of building regulatory enforcement inspectors are identified. They are: Safety or Building Inspectors who are employees of local government; specification inspectors who are construction professionals engaged by the owner of a building under construction to ensure compliance with his qualitative desires and the Federal Government inspectors who enforce federal regulation on federal issues such as health, energy, environmental protection e.t.c on federal government funded projects. Others include Public works inspectors who are concerned with conformity with contracts and specification documents as well as specialist inspectors who are to inspect and certify certain types of critical installations such as high-strength concrete, structural welding; highly stressed masonry e.t.c. Table1 illustrates some of the reported cases of building collapse in Nigeria from 1974 to 2010.

The Oxford Advanced Learner's Dictionary defined informal sector as a relaxed and friendly sector, not following strict rules of how to behave or do. In the same vein, Uwakweh (2000) describes the informal sector as "that segment of firms or individuals that engage in construction or other activities without obtaining the necessary designs, planning and construction documents". In other words, they always evade the formal process of obtaining permits and approvals for their construction and related activities. According to Uwakwah (2000), there are more informal construction programmes in the rural areas than in the cities but informal construction also flourish in the urban areas because of the illegal structures that exist on the outskirts of the urban areas. The informal sector rarely attracts high caliber workers who prefer to work for the larger contractors and the foreign firms.

While it is certain that buildings are prone to deterioration and may not be possible to generally avert failure, it is also expedient that the rate of collapse and the associated loss should be greatly reduced. Based on the results obtained by Folagbade (2001), i.e. 76\% of the reported collapsed buildings in Lagos state from 1980 to 1999 were private buildings, then the activities of the informal sector need to be investigated. This paper therefore takes a critical look at the incessant cases building collapse in Nigeria by identifying the likely causes and also investigates the activities of the informal sector in this context. The main objectives are to identify the likely causes of building collapse in Nigeria and to also investigate the contributory role of the informal sector to this incidence.

\subsection{Research Methodology}

To achieve these objectives, a survey was carried out on a target population of 150 contractors/developers as well as 150 clients of completed/on-going buildings in the six goe-political regions of Nigeria who were randomly selected from the study area. For each of the two categories of respondents, twenty five (25) copies of well-structured questionnaires were administered to each of the six geo-political zones in a manner that ensure even distribution across the region. The six geo-political regions of the country and the states covered are: Southwest (Lagos), Southeast (Abia), South-south (PortHarcourt), Northwest (Sokoto), Northeast (Borno) and the North Central (Benue). From these distributions, 90 and 95 questionnaires were respectively filled out and returned by the contractors and the clients (This is further shown in Table 2). The questionnaires survey were combined with direct interviews and site observations, especially with the illiterate and occupied respondents. The method of data analysis employed for this study was the Descriptive Analytical Technique. 


\subsubsection{Data Presentation and Discussion of Findings}

The occurrences of building collapse across the building categories in Nigeria from 1980 to the present date was investigated and the findings are presented in Table 3, which revealed that not less than 60 cases of building collapse occurred during this period. $42(70.0 \%)$ of these cases occurred in private buildings, 14 cases $(23.3 \%)$ occurred in the public setting while only 4 cases $(6.7 \%)$ were associated with the corporate organizations. The high figure recorded under private building might not be unconnected with the hasty and carefree manners in which most private clients handle their building projects. This lends credence to Folagbade (2001)'s works that private sector accounted for the bulk (76\%) of reported cases of building collapse between 1980 and 1991 in Lagos state and that hasty construction accounted for some of the major causes of building collapse in Nigeria.

Based on these findings, the questionnaire sought to examine the level of compliance with the building plan approval before the commencement of their construction. The result presented in Table 4 indicated that 29 respondent contractors (representing 32.2\%) managed to secure building plan approval before the construction commencement while a vast number of them (61 people, representing 67.8\%) evaded the approval before starting the construction works for their clients. Similar trends were also observed in the case of the clients, where $75 \%$ of them failed to secure building approval before the commencement of their construction works.

The evasion of necessary building plan by these two categories of respondents justified the need to investigate the registration categories of these contractors with the Federal Registration Board of Nigeria and the number of permanent employees in their payroll. This is with a view to understand their levels of formality and firms' classifications (e.g. large sized firms, medium-size firms and small-sized firms). Currently, the Federal Registration Board of Nigeria has four categories of registration which are based on their contract values. They are Category A (Contract sum up to N2 Million); Category B (N2 Million - N25 Million); Category C (N25 Million - N100 Million) and Category D (Above N100 Million). [N150=\$1]. The results in Table 5 revealed that 72 of the respondents $(80.0 \%)$ are registered under category A of the Federal Registration Board of Nigeria, 12 of them $(13.3 \%)$ have category $\mathrm{B}$ registration, four $(4.5 \%)$ registered under category $\mathrm{C}$ while two of the respondents $(2 \%)$ have category D registration. Also, 81 of the contractors $(90.0 \%)$ keep up to 10 permanent employees in their pay roll, of which only 6 of them (6.7\%) was able to keep up to 50 permanent employees in their pay roll, while 2 firms (2.2\%) and 1 firm (1.1\%) have permanent employees of up to 80 and above one 100 permanent employees respectively. According to the construction firm's classification by Ward (1979), the bulk of the surveyed contractors fall within the small sized category in terms of the revealed parameters in the findings, hence, the influence by domineering role of the informal sector is observed in construction activities in the rural areas and the outskirts of the urban centres of the country. This supports the view of Uwakweh (2000) that informal settings are more pronounced in the rural areas than the urban centre and that they fall within the small sized category with little or no level of formalities.

As a consequence of these findings, the questionnaires sought to understand the level of effectiveness of monitoring of building construction activities by the appropriate government agencies across the six geo-political regions of the country. The results in Table 6 showed that $72(80.0 \%)$ of the contractors attested to the ineffectiveness of the monitoring activities of construction works by the relevant government agencies while 18 of them $(20.0 \%)$ affirmed that the monitoring activities of construction works are very effective. Similar sentiments were also shared by the clients as 87 of the respondents $(91.6 \%)$ attested to the ineffectiveness of the monitoring of construction activities by the relevant government agencies while $8(8.4 \%)$ of them affirmed that the monitoring activities are effective. The ineffectiveness of the relevant government agencies in this perspective might be responsible for the high number of reported cases of building collapse in the private sector which are dominated by the informal setting.

Moreover, in Table 6, the questionnaire further to understand the awareness among contractors and the clients about the existing Building/Planning Regulations in their different states/regions (Table 7). The result surprisingly revealed that a vast number of these respondents were quite aware of the existence of the Building/Planning Regulations in the country. For example, 81 (90.0\%) of the respondent contractors attested to the awareness of these regulations in their various domains while a few of them ( 9 or $10.0 \%)$ claimed ignorance of the existence of these regulations. For the clients, $78(82.1 \%)$ claimed that they were aware of the existence of the Building/Planning Regulations in their domains while 17 (17.9\%) of them claimed ignorance of these regulations.

As shown in Tables 6 and 7, a vast number of these stakeholders are quite aware of the existing building/planning regulations in their various states/regions but just capitalized on the ineffective nature of the monitoring agencies across the country by doing things in the wrong way. This confirms the observation by Uwakweh (2000) that the informal sectors evade the formal process of obtaining permits and approvals for their construction programs and activities.

In addition to these findings, the questionnaire sought to investigate the perceived causes of building collapse in Nigeria in relation to the existing Building Regulations. Table 8 shows that $36.0 \%$ of the causes were as a result of non-possession of approved drawing. Only $19.0 \%$ was as a result of possession of approved drawing, $17.0 \%$ 
occurred as a result of approved drawings but non-compliance and/or use of poor quality materials. $15.0 \%$ possessed approved drawings but the construction works were performed by unqualified people while $13.0 \%$ of them possessed the necessary building drawings and complied with the approved drawings but used poor quality building materials for their construction works. This result further attested to the weakness of the relevant government agencies in ensuring standard in the construction industry in Nigeria. The incessant cases of building collapse in the country might also be attributed to this neglect.

\section{Conclusion and Recommendations}

From the foregoing analysis and discussions presented, it can be inferred that up to $70 \%$ of the cases of reported building collapse from 1980 to date occurred in the private setting which is largely domiciled by the informal sector. Also, the level of compliance with the approval of building plans before construction commencement is very low. This could be hinged on the ineffective monitoring mechanism put in place by the relevant government agencies and the low level of awareness of the existing Building/Planning Regulations by clients/contractors. It must be stressed that apart from the economic waste exhibited by building collapse, the occasional loss of lives is having devastating effects on the dwellers and the progress of the nation. This definitely calls for a proactive action in this perspective.

The following are therefore recommended in order to minimize the incessant building failure/collapse in the country.

1) More awareness campaigns should be carried out by the three tiers of government and their agencies on the need for compliance with the appropriate building regulations (e.g. among contractors, professionals, stakeholders and the general public) and the dangers associated with their none-compliance/evasion.

2) The Town Planning Authority should maintain competent professionals in the relevant areas for design approval and from a long term perspective, provide the necessary training. Moreover, there should be regular monitoring visits to all the construction sites with a view to ensuring compliance with the approved building plans.

3) More attention should be focused towards the private or informal sector, with a view to curbing their excesses.

4) Policy makers in the country should be less suspicious of professional advice as such advices are based on pre-determined principles and deviation which may result in predictable consequence in the near future.

5) There is a need for further awareness-raising on the danger in patronizing incompetent people for construction activities.

6) Government must be ready to tackle the challenges of building neglect by the populace. This should be inform of legislation, enforcement, support and assistance, publicity and education.

7) Stiffer penalties (such as jail or death sentences) should be placed on owners of collapse buildings and the project handlers in the country, especially where loss of lives is involved. This will serve as a deterrent to the carefree developers in the country.

This study had investigated the activities of the informal sector on the incessant cases of building collapse in Nigeria, it will be appropriate if similar investigations are carried out in other nations of Africa and beyond. This is with a view to networking research activities and come out with long lasting suggestions/policies that will go a long way in reducing/curbing this ugly development.

\section{References}

Adebayo, S. O. (2000). Improving Building Techniques, Proceedings of a Workshop on Building Collapse: Causes, Prevention and Remedies. The Nigerian Institute of Building, Lagos State Chapter, April.

Ademoroti, G. (1991). Minimizing the Collapse of Buildings in Lagos State. Proceedings of the National Seminar on effective Contract Management in Construction Industry, Nigerian Institute of Building, 22-23 August, pp 174-187.

Amusan, J. O. (1991). Strategies for Enhancing the Local Governments Roles in Minimizing the Collapse of Buildings. Proceedings of the National Conference on Effective Contract Management in the Construction Industry. Nigerian Institute of Building, 22-23August, pp188-200.

Badejo, E. (2009). Engineers, Others Urge Multi-Disciplinary Approach to Curb Building Collapse, The Guardian Newspaper, 13 July, pp 15-17.

Chinwokwu, G. (2000). The Role of Professionals In Averting Building Collapse, Proceedings of a Seminar on Building Collapse in Nigeria. The Nigerian Institute of Building, Lagos. Pp12-28.

Dare, S. (2001). Building Design, Buildability and Site Production. Proceedings of a Workshop on Building Collapse: Causes, Prevention and Remedies, The Nigerian Institute of Building, Ondo State, 23-24October.

Fadamiro, J. A. (2001). An Assessment of Building Regulations and Standards and The Implications for Building Collapse in Nigeria. Proceedings of a Workshop on Building Collapse: Causes, Prevention and Remedies, The Nigerian Institute of Building, Ondo State, 23-24 October. 
Folagbade, S. O. (2001). Case Studies of Building Collapse In Nigeria. Proceedings of a Workshop on Building Collapse,_Causes, Prevention and Remedies, The Nigerian Institute of Building, Ondo State Chapter, 23-24October.

Honby, A.S. (2000). Oxford Advanced learner's Dictionary. Oxford University Press, $6^{\text {th }}$ Ed. P. 952.

Makinde, F. A. (2007). Minimizing the Collapse of Building in Nigeria. Seminar Paper, Faculty of Environmental Studies, Osun State College of Technology, Esa-Oke, 20-21 August.

Makinde, R. (1998). Building Collapse in Nigeria. A Workshop Paper on Building Collapse, Nigerian Institute of Building, Osun State Chapter, 22- 24 November.

Uwakweh, B.O. (2000). Conceptual Framework for Motivating Construction workers in Developing Countries. Proceedings of the $2^{\text {nd }}$ International Conference of the CIB Task Group on Construction in Developing Countries, Faculty of Engineering and Technology, University of Botswana, Botswana, 15-17 Nov., pp31-37.

Ward, P.A (1979). Organizing and Proceedings in the Construction Industry, Plymouths MacDonald and Evans Ltd, pp 135-137.

Table 1. Some of the Reported Cases of Collapsed Buildings in Nigeria (1974 - 2010)

\begin{tabular}{|c|c|c|c|c|c|}
\hline $\mathbf{S} / \mathbf{N}$ & $\begin{array}{l}\text { TYPE OF } \\
\text { BUILDING } \\
\text { STRUCTURE }\end{array}$ & $\begin{array}{ll}\text { LOCATION } & \text { OF } \\
\text { BUILDING } & \end{array}$ & $\begin{array}{l}\text { DATE OF } \\
\text { COLLAPSE }\end{array}$ & $\begin{array}{l}\text { SUSPECTED } \\
\text { CAUSE(S) }\end{array}$ & $\begin{array}{l}\text { REMARKS } \\
\text { (LIVES } \\
\text { LOST) }\end{array}$ \\
\hline 1. & $\begin{array}{l}\text { Multi-storey } \\
\text { Building under } \\
\text { construction }\end{array}$ & $\begin{array}{l}\text { Mokola, Ibadan, Oyo } \\
\text { State }\end{array}$ & October 1974 & $\begin{array}{l}\text { Excessive } \\
\text { loading/structural failure }\end{array}$ & 27 people \\
\hline 2. & $\begin{array}{l}\text { Partial collapse } \\
\text { of an Hostel } \\
\text { Building }\end{array}$ & $\begin{array}{l}\text { O.A.U., } \\
\text { Ile-ife }\end{array}$ & $\begin{array}{l}1976 \\
(1975 / 76 \\
\text { Academic } \\
\text { Session }\end{array}$ & Structural Failure & Nil \\
\hline 3. & $\begin{array}{l}\text { Residential } \\
\text { Building }\end{array}$ & $\begin{array}{l}\text { Barnawa housing Estate, } \\
\text { Kaduna, State }\end{array}$ & August 1977 & Faulty design & 28 people \\
\hline 4. & School Building & $\begin{array}{l}\text { Government Secondary } \\
\text { school, makarfi, Kaduna } \\
\text { State }\end{array}$ & July 1977 & Carelessness & 7 people \\
\hline 5. & $\begin{array}{l}\text { 3-Storey } \\
\text { Residential } \\
\text { Building }\end{array}$ & $\begin{array}{l}\text { Barnawa Housing Estate } \\
\text { Kaduna }\end{array}$ & 1980 & Faulty Structural design & 6 people \\
\hline 6. & $\begin{array}{l}\text { Storey } \\
\text { Residential } \\
\text { Building }\end{array}$ & $\begin{array}{ll}\text { Allen } & \text { Avenue, Ikeja } \\
\text { Lagos } & \end{array}$ & Jnauary 1985 & Excessive Loading & Nil \\
\hline 7. & $\begin{array}{l}\text { Residential } \\
\text { Building }\end{array}$ & Adeniji Adele, Lagos & $\begin{array}{l}\text { February } \\
1985\end{array}$ & Excessive Loading & 2 people \\
\hline 8. & $\begin{array}{l}\text { Residential } \\
\text { Building }\end{array}$ & Ojuelegba Area, Lagos & May 18,1985 & Rainstorm & Nil \\
\hline 9. & $\begin{array}{l}\text { Residential } \\
\text { Building } \\
\text { (Uncompleted } 4 \\
\text { Storey Building) }\end{array}$ & Iponri, Lagos & May 20, 1985 & Structural Failure & 13 people \\
\hline 10. & $\begin{array}{l}\text { Residential } \\
\text { Building }\end{array}$ & Victoria Island, Lagos & July 18,1985 & Excessive Loading & $\begin{array}{l}13 \text { people } \\
\text { (all of the } \\
\text { same family }\end{array}$ \\
\hline 11. & $\begin{array}{l}\text { Residential } \\
\text { Building }\end{array}$ & Gboko, Benue State & $\begin{array}{l}\text { September, } \\
1985\end{array}$ & Carelessness & 1 person \\
\hline 12. & $\begin{array}{l}\text { Residential } \\
\text { Building }\end{array}$ & Allen Avenue & 1985 & Carelessness & Nil \\
\hline 13. & $\begin{array}{l}\text { Residential } \\
\text { Building }\end{array}$ & Adeniji Adele, Lagos & 1985 & $\begin{array}{l}\text { Faulty design/ } \\
\text { Carelessness }\end{array}$ & 2 people \\
\hline
\end{tabular}




\begin{tabular}{|c|c|c|c|c|c|}
\hline 14. & $\begin{array}{ll}\text { High } & \text { Court } \\
\text { Building } & \end{array}$ & Isala Area, Imo State & $\begin{array}{l}\text { February } \\
1986\end{array}$ & Structural Failure & 2 people \\
\hline 15. & $\begin{array}{l}\text { Mosque } \\
\text { Building }\end{array}$ & Oshogbo, Osun State & May, 1986 & Structural Failure & 2 people \\
\hline 16. & $\begin{array}{l}\text { Residential } \\
\text { Building }\end{array}$ & $\begin{array}{l}\text { Ona Street Enugu, } \\
\text { Enugu State }\end{array}$ & 1986 & No Investigation & 2 people \\
\hline 17. & $\begin{array}{l}\text { 2-Storey } \\
\text { Building under } \\
\text { construction }\end{array}$ & Agege, Lagos & May 9, 1987 & Structural Fault & 2 people \\
\hline 18. & $\begin{array}{l}\text { Residential } \\
\text { Building }\end{array}$ & $\begin{array}{l}\text { Idusagbe Lane, Idumota } \\
\text { Lagos }\end{array}$ & $\begin{array}{l}\text { September } \\
14,1987\end{array}$ & No Structural Design & 17 people \\
\hline 19. & $\begin{array}{l}\text { Commercial } \\
\text { Building }\end{array}$ & Ikorodu Road, Lagos & $\begin{array}{l}\text { September } \\
1987\end{array}$ & Rainstorm & 4 people \\
\hline 20. & $\begin{array}{l}\text { Residential } \\
\text { Building }\end{array}$ & $\begin{array}{l}\text { Calabar, Cross River } \\
\text { State }\end{array}$ & $\begin{array}{l}\text { October } 9, \\
1987\end{array}$ & Rainstorm & 3 people \\
\hline 21. & $\begin{array}{ll}\text { 6-storey } & \text { Hotel } \\
\text { Building } & \\
\end{array}$ & $\begin{array}{l}\text { Akinwunmi street, } \\
\text { Mende Village, Lagos }\end{array}$ & October 1989 & Faulty design & Nil \\
\hline 22. & $\begin{array}{l}\text { Bungalow } \\
\text { School Building }\end{array}$ & $\begin{array}{l}\text { Port Harcourt, Rivers } \\
\text { State }\end{array}$ & June 15,1990 & $\begin{array}{l}\text { Ignorance of the owner } \\
\text { and absence of structural } \\
\text { design }\end{array}$ & Nil \\
\hline 23. & $\begin{array}{l}\text { 6-storey Hotel } \\
\text { Complex }\end{array}$ & $\begin{array}{l}\text { Okupe Estate Maryland, } \\
\text { Lagos }\end{array}$ & 1993 & Structural Failure & Not Known \\
\hline 24. & $\begin{array}{l}\text { Multi-purpose } \\
\text { Indoor Sports } \\
\text { Complex Storey }\end{array}$ & Area 10, Abuja & March 1993 & $\begin{array}{l}\text { Structural failure/Poor } \\
\text { workmanship }\end{array}$ & Not reported \\
\hline 25. & $\begin{array}{l}\text { Multi-storey } \\
\text { Building } \\
\text { NICON-NOGA } \\
\text { Staff Housing } \\
\text { Project }\end{array}$ & Karo, Abuja & $\begin{array}{l}\text { March 25, } \\
1993\end{array}$ & $\begin{array}{l}\text { Structural failure/use of } \\
\text { incompetent people for } \\
\text { Supervision }\end{array}$ & Not reported \\
\hline 26. & $\begin{array}{l}\text { A Mosque } \\
\text { Building under } \\
\text { construction }\end{array}$ & Abeokuta Ogun State & 1995 & $\begin{array}{l}\text { Structural failure/use of } \\
\text { incompetent people for } \\
\text { Supervision }\end{array}$ & 2 people \\
\hline 27. & $\begin{array}{l}\text { Storey Building } \\
\text { (under } \\
\text { construction) }\end{array}$ & Central Lagos & $\begin{array}{l}\text { October } 5, \\
1995\end{array}$ & $\begin{array}{l}\text { Poor workmanship/ } \\
\text { structural failure }\end{array}$ & 10 people \\
\hline 28. & $\begin{array}{l}\text { 3-storey Church } \\
\text { Building }\end{array}$ & Lagos & $\begin{array}{l}\text { October 30, } \\
1995\end{array}$ & Structural failure & 6 people \\
\hline 29. & School Building & $\begin{array}{l}\text { Alagbado Area, Ibadan } \\
\text { Oyo State }\end{array}$ & October 1995 & Poor workmanship & Nil \\
\hline 30. & $\begin{array}{l}\text { 3-Storey } \\
\text { Building }\end{array}$ & $\begin{array}{l}\text { Oke Igbala Area, Ibadan } \\
\text { Oyo State }\end{array}$ & October 1995 & Structural failure & 6 people \\
\hline 31. & $\begin{array}{l}\text { 1-stroey } \\
\text { Building under } \\
\text { construction but } \\
\text { being used as } \\
\text { church (Earlier } \\
\text { approved as a } \\
\text { bungalow }\end{array}$ & $\begin{array}{lr}\text { Olowookere } & \text { street, } \\
\text { Mafoluku, } & \text { Oshodi, } \\
\text { Lagos } & \end{array}$ & June 1996 & Structural Weakness & 7 people \\
\hline 32. & $\begin{array}{l}\text { Storey Building } \\
\text { under } \\
\text { construction }\end{array}$ & Lagos State & $\begin{array}{l}\text { March 13, } \\
1996\end{array}$ & Structural failure & $\begin{array}{l}\text { People only } \\
\text { injured }\end{array}$ \\
\hline
\end{tabular}




\begin{tabular}{|c|c|c|c|c|c|}
\hline 33. & $\begin{array}{l}\text { 6-Storey } \\
\text { Building under } \\
\text { construction } \\
\text { (being used as } \\
\text { Nursery/Primary } \\
\text { School) }\end{array}$ & Lagos State & $\begin{array}{l}\text { October, } \\
1996\end{array}$ & $\begin{array}{l}\text { Use of quacks/Structural } \\
\text { Failure }\end{array}$ & 1 person \\
\hline 34. & $\begin{array}{l}\text { 2-Storey } \\
\text { Building }\end{array}$ & $\begin{array}{l}\text { Amu Street, Mushin, } \\
\text { Lagos }\end{array}$ & June, 1997 & $\begin{array}{ll}\text { Use of poor } \\
\text { materials/structural } \\
\text { failure }\end{array}$ & Nil \\
\hline 35. & Duplex Building & $\begin{array}{l}\text { Gwarinpa Area, FCT, } \\
\text { Abuja }\end{array}$ & 1998 & Structural failure & 2 people \\
\hline 36 & $\begin{array}{l}\text { 3-Storey } \\
\text { Residential } \\
\text { Building }\end{array}$ & Ibadan, Oyo State & 1998 & $\begin{array}{l}\text { Faulty, Design/Poor } \\
\text { workmanship }\end{array}$ & $\begin{array}{l}\text { Several } \\
\text { people }\end{array}$ \\
\hline 37. & $\begin{array}{l}\text { 4-Storey Church } \\
\text { Building (under } \\
\text { construction) }\end{array}$ & Akure, Ondo State & $\begin{array}{l}\text { October } 1, \\
1998\end{array}$ & $\begin{array}{ll}\text { Structural } & \text { failure/Poor } \\
\text { Supervision } & \end{array}$ & 8 People \\
\hline 38. & $\begin{array}{l}\text { 2-Storey } \\
\text { Residential } \\
\text { Building }\end{array}$ & $\begin{array}{l}\text { Rd 3, Plot 10, Funbi } \\
\text { Fagun Street, Abeokuta, } \\
\text { Ogun State }\end{array}$ & $\begin{array}{l}\text { November, } \\
1998\end{array}$ & $\begin{array}{l}\text { Use of } \\
\text { materials/structural }\end{array}$ & Nil \\
\hline 39. & $\begin{array}{l}\text { 3-Storey } \\
\text { Residential } \\
\text { Building }\end{array}$ & $\begin{array}{l}\text { Ojuelegba, Western } \\
\text { Avenue, Surulere, Lagos } \\
\text { State }\end{array}$ & 1999 & $\begin{array}{l}\text { Carelessness/use of poor } \\
\text { materials }\end{array}$ & 4 people \\
\hline 40. & $\begin{array}{l}\text { 1-Storey } \\
\text { Residential }\end{array}$ & $\begin{array}{l}\text { Adeola Odeku Street, } \\
\text { Victoria Island, Lagos }\end{array}$ & 1999 & Rainstorm & Not reported \\
\hline 41. & $\begin{array}{l}\text { 3-Storey } \\
\text { Residential } \\
\text { Building }\end{array}$ & $\begin{array}{l}\text { Charity Road, Oko-Oba, } \\
\text { Lagos }\end{array}$ & June 1999 & Structural failure & Nil \\
\hline 42 & $\begin{array}{l}\text { 3-Storey } \\
\text { Residential }\end{array}$ & $\begin{array}{ll}\text { Four-square } & \text { Gospel } \\
\text { Church Abuja } & \\
\end{array}$ & $\begin{array}{l}\text { October, } \\
1999\end{array}$ & $\begin{array}{ll}\text { Faulty } & \text { design/ } \\
\text { Implementation }\end{array}$ & $\begin{array}{l}\text { Not } \\
\text { Available }\end{array}$ \\
\hline 43. & $\begin{array}{l}\text { 1-Storey } \\
\text { Residential } \\
\text { Building }\end{array}$ & $\begin{array}{l}\text { Obawole street, Iju, } \\
\text { Agege, Lagos }\end{array}$ & $\begin{array}{l}\text { October, } \\
1999\end{array}$ & Structural failure & Nil \\
\hline 44. & $\begin{array}{l}\text { 3-Storey } \\
\text { Residential } \\
\text { Building }\end{array}$ & Iju-Isaga, Lagos & August, 1999 & $\begin{array}{l}\text { Structural } \\
\text { Faulty/Rainstorm }\end{array}$ & 35 people \\
\hline 45. & $\begin{array}{l}\text { 2-Storey } \\
\text { Residential } \\
\text { Building }\end{array}$ & $\begin{array}{l}\text { Dawodu street, Ifo, } \\
\text { Ogun State }\end{array}$ & $\begin{array}{l}\text { October, } \\
1999\end{array}$ & Rainstorm & 20 people \\
\hline 46. & $\begin{array}{l}\text { Residential } \\
\text { Storey Building }\end{array}$ & Idi-Oro, Mushin, Lagos & 2000 & $\begin{array}{l}\text { Faulty } \\
\text { Design/Carelessness }\end{array}$ & $\begin{array}{l}\text { Not } \\
\text { Available }\end{array}$ \\
\hline 47. & $\begin{array}{l}\text { Estate } \\
\text { Building } \\
\end{array}$ & $\begin{array}{l}\text { Ajah, Along Lekki } \\
\text { Road, Lagos }\end{array}$ & April, 2000 & Structural Failure & Nil \\
\hline 48. & $\begin{array}{l}\text { 2-Storey } \\
\text { Mosque } \\
\text { Building }\end{array}$ & $\begin{array}{lr}21, \quad \text { Buhari } & \text { Street } \\
\text { Mushin, Lagos } & \end{array}$ & April 2001 & $\begin{array}{l}\text { Unauthorized Conversion } \\
\text { of former Bungalow to 2- } \\
\text { Storey Building }\end{array}$ & 7 people \\
\hline 49. & $\begin{array}{l}\text { 1-Storey } \\
\text { Residential } \\
\text { Building (under } \\
\text { construction) }\end{array}$ & Iwoye-Ijesa, Osun State & 2001 & $\begin{array}{l}\text { Structural failure/ use of } \\
\text { quacks for supervision }\end{array}$ & 7 people \\
\hline 50. & $\begin{array}{l}\text { Multi-storey } \\
\text { Commercial } \\
\text { Residential } \\
\text { Building }\end{array}$ & Ebute-Meta, Lagos & 2007 & $\begin{array}{l}\text { Unauthorized } \\
\text { conversion/poor } \\
\text { supervision/use of quality } \\
\text { materials }\end{array}$ & $\begin{array}{l}\text { Several } \\
\text { people }\end{array}$ \\
\hline
\end{tabular}




\begin{tabular}{|c|c|c|c|c|c|}
\hline 51. & $\begin{array}{l}\text { Multi-Storey } \\
\text { Building }\end{array}$ & Kano & 2007 & $\begin{array}{l}\text { Faulty design/structural } \\
\text { failure }\end{array}$ & $\begin{array}{l}\text { Several } \\
\text { people }\end{array}$ \\
\hline 52. & $\begin{array}{l}\text { A Building } \\
\text { being used as } \\
\text { Nursery/Primary } \\
\text { School }\end{array}$ & $\begin{array}{l}\text { Olomi Area Ibadan, Oyo } \\
\text { State }\end{array}$ & $\begin{array}{l}\text { March 25, } \\
2008\end{array}$ & $\begin{array}{l}\text { Use of poor materials } \\
\text { carelessness }\end{array}$ & 13 pupils \\
\hline 53. & $\begin{array}{l}\text { 5-Storey } \\
\text { Shopping } \\
\text { Complex } \\
\text { Building under } \\
\text { construction }\end{array}$ & Wuse Area, Abuja & $\begin{array}{l}2^{\text {nd }} \text { August, } \\
2008\end{array}$ & $\begin{array}{l}\text { Structural failure } \\
\text { incompetency/bad } \\
\text { workmanship }\end{array}$ & $\begin{array}{l}2 \text { people } \\
\text { injured and } \\
100 \text { people } \\
\text { trapped. }\end{array}$ \\
\hline 54. & $\begin{array}{l}\text { 2-Storey } \\
\text { Residential } \\
\text { Building under } \\
\text { construction }\end{array}$ & $\begin{array}{l}\text { Asero Area, Abeokuta } \\
\text { Ogun State }\end{array}$ & $\begin{array}{rr}30^{\text {th }} & \text { August } \\
2008 & \end{array}$ & $\begin{array}{l}\text { Contravening the given } \\
\text { planning Approval, use } \\
\text { of substandard materials } \\
\text { incompetency, etc. }\end{array}$ & 2 people \\
\hline 55. & $\begin{array}{l}\text { 6-Storey } \\
\text { LAUTECH } \\
\text { Teaching } \\
\text { Hospital } \\
\text { Complex under } \\
\text { construction }\end{array}$ & Ogbomoso, Oyo State & $\begin{array}{l}19^{\text {th }} \text { February, } \\
2009\end{array}$ & $\begin{array}{lr}\text { Use of } & \text { substandard } \\
\text { materials, } & \text { poor } \\
\text { workmanship/supervision }\end{array}$ & 5 people \\
\hline 56 & A wall fence & $\begin{array}{l}\text { Aghaji crescent, GRA, } \\
\text { Enugu }\end{array}$ & $\begin{array}{l}10^{\text {th }} \text { August, } \\
2009\end{array}$ & No proper drainage & 1 person \\
\hline 57 & $\begin{array}{l}\text { Uncompleted } \\
\text { Building }\end{array}$ & $\begin{array}{l}\text { Oke Padre Street, } \\
\text { Ita-morin, Abeokuta }\end{array}$ & $\begin{array}{l}18^{\text {th }} \text { October, } \\
2009\end{array}$ & $\begin{array}{lr}\text { Use of } & \text { substandard } \\
\text { materials, } & \text { hasty } \\
\text { construction } & \end{array}$ & $\begin{array}{l}3 \text { people, } 11 \\
\text { injured }\end{array}$ \\
\hline 58 & $\begin{array}{l}\text { Building under } \\
\text { Construction }\end{array}$ & $\begin{array}{l}\text { Isopakodowo Street } \\
\text { Cairo, Oshodi, Lagos }\end{array}$ & $\begin{array}{l}26^{\text {th }} \quad \text { April, } \\
2010\end{array}$ & $\begin{array}{l}\text { Use of Substandard } \\
\text { building materials }\end{array}$ & $\begin{array}{l}4 \text { people, } 12 \\
\text { injured }\end{array}$ \\
\hline 59 & $\begin{array}{l}\text { Uncompleted } \\
\text { Storey building }\end{array}$ & $\begin{array}{l}\text { Adenike Street off New } \\
\text { market, Oniru Estate, VI }\end{array}$ & $\begin{array}{l}2^{\text {nd }} \quad \text { June, } \\
2010\end{array}$ & $\begin{array}{l}\text { Use of Substandard } \\
\text { building materials, } \\
\text { Non-compliance r o } \\
\text { house-owners and } \\
\text { developers with approved } \\
\text { building plan and weak } \\
\text { structure }\end{array}$ & $\begin{array}{l}1 \text { person, } 2 \\
\text { injured }\end{array}$ \\
\hline 60 & $\begin{array}{l}\text { Uncompleted } \\
\text { 4-Storey } \\
\text { Building }\end{array}$ & $\begin{array}{l}2 \text { Okolie Street, off } \\
\text { Gimbiya Street in Abuja. }\end{array}$ & $\begin{array}{l}11^{\text {th }} \text { August, } \\
2010\end{array}$ & $\begin{array}{l}\text { Substandard materials } \\
\text { and disregard for } \\
\text { building regulations }\end{array}$ & $\begin{array}{l}23 \text { people, } 11 \\
\text { injured }\end{array}$ \\
\hline 61 & $\begin{array}{ll}4 & \text { Storey } \\
\text { Building } & \end{array}$ & $\begin{array}{l}24 \text { Alli Street off Tinubu } \\
\text { Street, V. I. }\end{array}$ & $\begin{array}{l}28^{\text {th }} \\
\text { September, } \\
2010\end{array}$ & $\begin{array}{l}\text { Structural } \\
\text { Defects/overloading }\end{array}$ & 3 people \\
\hline
\end{tabular}

Table 2. Questionnaires Distribution to the Respondents and the Response Rates

\begin{tabular}{|l|l|l|l|l|l|l|}
\hline \multicolumn{2}{|l|}{} & Questionnaire Distribution & \multicolumn{2}{l|}{ Response Rate } \\
\hline S/N & $\begin{array}{l}\text { Geopolitical } \\
\text { Regions }\end{array}$ & $\begin{array}{l}\text { States } \\
\text { Covered }\end{array}$ & Contractors & Clients & Contractors & Clients \\
\hline 1 & Southwest & Lagos & 25 & 25 & 22 & 23 \\
2 & Southwest & Abia & 25 & 25 & 12 & 14 \\
3 & Southwest & Pothharcourt & 25 & 25 & 17 & 18 \\
4 & Northwest & Sokoto & 25 & 25 & 14 & 15 \\
5 & Northeast & Borno & 25 & 25 & 13 & 12 \\
6 & Northcentral & Benue & 25 & 25 & 12 & 13 \\
\hline & Total & & $\mathbf{1 5 0}$ & $\mathbf{1 5 0}$ & $\mathbf{9 0}$ & $\mathbf{9 5}$ \\
\hline
\end{tabular}


Table 3. Cases of Building collapse across the Building Categories in Nigeria (1980 2010)

\begin{tabular}{|l|l|l|l|}
\hline S/N & $\begin{array}{l}\text { Building } \\
\text { Categories }\end{array}$ & No of Cases & $\begin{array}{l}\text { Percentage } \\
\text { Occurrences (\%) }\end{array}$ \\
\hline 1 & Private & 42 & 70.0 \\
2 & Public & 14 & 23.3 \\
3 & Corporate & 4 & 6.7 \\
\hline & Total & $\mathbf{6 0}$ & $\mathbf{1 0 0 . 0}$ \\
\hline
\end{tabular}

Table 4. Compliance with the Approval of Building Plan before Construction Commencement (Contractors \& Clients)

\begin{tabular}{|l|l|l|l|l|}
\hline Approval Secured & Contractor & \multicolumn{2}{l|}{ Clients } \\
\hline & $\begin{array}{l}\text { No of of } \\
\text { Respondents }\end{array}$ & \% Response & No Respondents & \% Response \\
\hline Yes & 29 & 32.2 & 22 & 23.2 \\
No & 61 & 67.8 & 73 & 76.8 \\
\hline
\end{tabular}

Table 5. Registration Categories of Contractors with the Federation Board Registration of Nigeria and the Number of Permanent Employees in their pay Roll

\begin{tabular}{|l|l|l|l|l|l|}
\hline \multicolumn{2}{|l|}{ Registration Categories } & \multicolumn{4}{l|}{ No of Permanent Employees } \\
\hline Category & $\begin{array}{l}\text { No of } \\
\text { Respondents }\end{array}$ & \% Response & Classification & $\begin{array}{l}\text { No of } \\
\text { Respondents }\end{array}$ & \% Response \\
\hline A & 72 & 80.0 & 1 to 10 & 81 & 90.0 \\
B & 12 & 13.3 & Up to 50 & 6 & 6.7 \\
C & 4 & 4.5 & Up to 80 & 2 & 2.2 \\
D & 2 & 2.2 & Above 100 & 1 & 1.1 \\
\hline
\end{tabular}

Table 6. Effectiveness of Monitoring of Construction Activities by the Relevant Government Agencies

\begin{tabular}{|l|l|l|l|l|l|}
\hline Contractors & Clients \\
\hline $\begin{array}{l}\text { Monitoring } \\
\text { Effectiveness }\end{array}$ & $\begin{array}{l}\text { No ospondents } \\
\text { Respespense }\end{array}$ & \% Response & $\begin{array}{l}\text { Monitoring } \\
\text { Effectiveness }\end{array}$ & $\begin{array}{l}\text { No } \\
\text { Respondents }\end{array}$ & \% Response \\
\hline Yes & 18 & $20.0 \%$ & Yes & 8 & $8.4 \%$ \\
No & 72 & $80.0 \%$ & No & 87 & $91.6 \%$ \\
\hline
\end{tabular}

Table 7. Awareness by Contractors and clients of Existing Building/Planning Regulations

\begin{tabular}{|c|c|c|c|c|c|}
\hline \multicolumn{3}{|c|}{ Contractors } & \multicolumn{3}{|l|}{ Clients } \\
\hline Awareness & $\begin{array}{l}\text { No of } \\
\text { Respondents }\end{array}$ & \% Response & Awareness & $\begin{array}{l}\text { No of } \\
\text { Respondents }\end{array}$ & \% Response \\
\hline Yes & 81 & $90.0 \%$ & Yes & 78 & $82.1 \%$ \\
\hline No & 9 & $10.0 \%$ & No & 17 & $17.9 \%$ \\
\hline
\end{tabular}

Table 8. Perceived causes of building collapse in Nigeria in Relation to Building_Regulations.

\begin{tabular}{|c|c|c|}
\hline $\mathbf{S} / \mathbf{N}$ & Perceived Cause & \% Response \\
\hline 1 & Non-possession of approved drawings. & $36.0 \%$ \\
\hline 2 & Possession of approved drawings but non-compliance. & $19.0 \%$ \\
\hline 3 & $\begin{array}{l}\text { Possession of approved drawings but non-compliance cum the } \\
\text { use of poor quality materials. }\end{array}$ & $17.0 \%$ \\
\hline 4 & $\begin{array}{l}\text { Possession of approved drawings but handled by } \\
\text { unqualified/wrong people. }\end{array}$ & $15.0 \%$ \\
\hline 5 & $\begin{array}{l}\text { Possession of and compliance with approved drawings but use } \\
\text { of poor quality building materials }\end{array}$ & $13.0 \%$ \\
\hline
\end{tabular}

